\title{
100 years \\ of continuous publishing of the Bratislava Medical Journal
}

Dear colleagues, readers of the Bratislava Medical Journal,

It is my honour and pleasure to have the opportunity to greet you all, the general medical community - doctors, pharmacists and other healthcare professionals - on the occasion of the 100th anniversary of the Bratislava Medical Journal, which will be commemorated in October this year. At the same time, to express thanks and respect not only to those, who contributed to establishing the tradition of this publication, but also to all the authors and readers, who contributed to achieving a high professional level of the journal meeting the demanding internationally accepted criteria required for scientific journals and its inclusion amidst the indexed journals in world databases. This meritorious historical deed was recognized by the parliament of the Slovak Republic also legislatively in 2001 and, in accordance with the Declaration of the National Council of the Slovak Republic, the Bratislava Medical Journal has justifiably become our cultural and scientific heritage. Equally meritorious is its re-publication by the Medical Faculty of Comenius University (since 1993), which, even from the international point of view of university evaluation, significantly increases the faculty's credit and the journal can be described as its "family silver".

I am proud and appreciate that the history of the journal is connected with the names of leading Czech and Slovak personalities of medical sciences from among the elite of our nation, world-renowned scientific, pedagogical and clinical staff, especially of the Medical Faculty of Comenius University and of the Slovak Academy of Sciences, who have successfully represented and who continue to represent the Slovak Medical Society in various leading positions and significantly contributed to its building and development. First Rector of Comenius University in Bratislava, the initiator of publishing and founder of the Bratislava Medical Journal, prof. MUDr. Kristián Hynek, was a long-term chairman of the Association of Czechoslovak Physicians in Bratislava (today the Association of Slovak Physicians in Bratislava, an organizational unit of 
the Slovak Medical Society). He insisted that lectures and minutes from the association's meetings are to be published in the Bratislava Medical Journal. The journal has thus become an important historical document about the activities of the association, about the ongoing discussions on professional medical issues and clinical knowledge gained at home and abroad, as well as providing information on the current events in health care. It is a tool for dissemination of scientifically proven medical knowledge (evidence-based medicine), a valuable source of study material both for medical students and students of healthcare-oriented universities, as well as for the first contact physicians and specialists. The journal is a picture of the development of medicine in our country.

Progressive development of the medical sciences, the rapid growth of new scientific discoveries and knowledge, scientific and technical progress and the development of new information and communication technologies are inevitably linked to the lifelong education of doctors and other health professionals. European Union directives oblige Member States to ensure continuous training of health professionals in order to continuously renew, deepen and maintain their professional competence and skills throughout the profession, in line with the development of the relevant medical disciplines. The Slovak Republic responded to this obligation by adopting legislative measures, various conceptual and strategic materials as the basic principle of education and vocational training in our country.

One of the forms and possibilities of continuous education of health professionals are scientific journals. Without them, there can be no scientific discipline, especially medicine. Throughout its existence, the Bratislava Medical Journal has become a part of the lifelong education of healthcare professionals. Thanks to the professional background and the quality of highly professional work of the members of the editorial board, for several decades under the leadership of prof. MUDr. Ivan Hulín, DrSc., the journal has retained its professional and scientific character and gained a prestigious position in the world, as evidenced every year by a growing interest in submitting and publishing papers. By publishing the journal in English in printed and electronic forms, the editors promptly responded to the requirements of modern forms of dissemination of professional information, which can be especially appreciated in the current "covid period". Professor Hulín's companion, 
especially in terms of a high culture of the texts, is PhDr. Helena Bernadičová, who has been the mainstay of the journal for almost the same long time. This is an admirable concurrence of two specialties in creating the journal and reaching its peaks.

The Bratislava Medical Journal is a valuable masterpiece, national cultural heritage, being the result of the work of exceptional, wise, educated people selflessly participating in its creation. We are rightfully proud of them. We value and appreciate that despite challenging social events, including a difficult period of transformation of our healthcare system with its serious economic impact on education and publishing of professional literature, they were able to maintain and increase the professional level and quality of the journal. Personalities such as prof. Hulín and members of the editorial board of the Bratislava Medical Journal are a guarantee that the journal will continue to be of high quality and will be one of the tools of professional education for the future generations of doctors and healthcare professionals for another century. I believe in it and wish it to all the members of the editorial board, contributors and the wider medical professional community.

Dr.h.c. prof. MUDr. Ján Breza, DrSc., MPH, MHA President of the Slovak Medical Association 


\section{0 rokov nepretržitého vydávania časopisu Bratislava Medical Journal}

Vážené kolegyne, vážení kolegovia, čitatelia časopisu Bratislavské lekárske listy,

je pre mňa ct'ou a potešením, že mi bolo umožnené pri príležitosti 100. výročia vydávania časopisu Bratislavské lekárske listy, ktoré sme si pripomenuli v októbri 2021, pozdravit' Vás - čitatel'ov, širokú odbornú medicínsku verejnost' - lekárov, farmaceutov a iných zdravotníckych pracovníkov. Zároveň vyslovujem vd'aku a úctu nielen tým, ktorí sa zaslúžili o založenie tradície jeho vydávania, ale aj všetkým tým, ktorí v nej pokračovali a pokračujú a prispeli k dosiahnutiu vysokej odbornej úrovne časopisu spĺňajúcej náročné medzinárodne akceptované kritériá vyžadované pre vedecký časopis a jeho zaradenie medzi indexované časopisy vo svetových databázach. Tento záslužný historický počin bol roku 2001 uznaný Národnou radou Slovenskej republiky aj legislatívne a Bratislavské lekárske listy sa v zmysle Deklarácie Národnej rady Slovenskej republiky opodstatnene stali naším kultúrnym a vedeckým dedičstvom. Rovnako záslužné je jeho opätovné vydávanie Lekárskou fakultou Univerzity Komenského (od roku 1993), čo aj z medzinárodného hl'adiska hodnotenia vysokých škôl výrazne zvyšuje kredit fakulty a časopis možno označit' za jej „rodinné striebro“.

Vážim si a som hrdý na to, že história časopisu je spojená s menami popredných českých a slovenských osobností medicínskych vied. Patria medzi elity našich národov, svetovo uznávaných vedeckých, pedagogických a klinických pracovníkov najmä Lekárskej fakulty Univerzity Komenského a Slovenskej akadémie vied, ktorí úspešne reprezentovali a reprezentujú aj Slovenskú lekársku spoločnost' v rôznych popredných funkciách a významnou mierou sa zaslúžili o jej budovanie a rozvoj. Prvý rektor Univerzity Komenského v Bratislave, iniciátor vydávania a zakladatel' Bratislavských lekárskych listov, prof. MUDr. Kristián Hynek, bol dlhoročným predsedom Spolku československých lekárov v Bratislave (dnes Spolku slovenských lekárov v Bratislave, organizačnej zložky Slovenskej lekárskej 
spoločnosti). Presadil, aby boli v Bratislavských lekárskych listoch zverejňované prednášky a zápisnice (protokoly) zo zasadnutí spolku. Časopis sa tak stal významným historickým dokumentom o činnosti spolku, prebiehajúcich diskusiách o odbornej medicínskej problematike a klinických poznatkoch získaných doma a v zahraničí, ako aj informácií o aktuálnom dianí v zdravotníctve. Je nástrojom šírenia vedecky overených medicínskych poznatkov (EBM), cenným zdrojom študijného materiálu pre medikov a študentov na zdravotníctvo zameraných vysokých škôl, ako aj pre lekárov prvého kontaktu a špecialistov, je obrazom vývoja medicíny u nás.

Progresívny rozvoj medicínskych vied, prudký nárast nových vedeckých objavov a poznatkov, vedecko-technický pokrok a rozvoj nových informačných a komunikačných technológií je nevyhnutne spojený s celoživotným vzdelávaním lekárov a iných zdravotníckych pracovníkov. Smernice Európskej únie ustanovujú členským štátom povinnost' zabezpečit' sústavné vzdelávanie zdravotníckych pracovníkov s ciel'om priebežného obnovovania si, prehlbovania a udržiavania odbornej spôsobilosti a profesijnej zručnosti po celý čas výkonu povolania, a to $\mathrm{v}$ súlade $\mathrm{s}$ rozvojom príslušných medicínskych odborov. Slovenská republika reagovala na túto povinnost' prijatím legislatívnych opatrení, rôznych koncepčných a strategických materiálov ako základný princíp výchovy a odborného vzdelávania u nás.

Jednou z foriem a možností sústavného vzdelávania sa zdravotníckych pracovníkov sú odborné časopisy. Bez nich nemôže existovat' žiadna vedecká disciplína, osobitne medicína. Bratislavské lekárske listy sa počas celej svojej existencie stali súčast’ou celoživotného vzdelávania zdravotníckych pracovníkov. Vd’aka odbornému autorskému zázemiu a kvalite vysokoprofesionálnej práce členov redakčnej rady už niekol'ko desiatok rokov pod vedením prof. MUDr. Ivana Hulína, DrSc., si časopis zachoval odborný a vedecký charakter a vo svete získal prestížne postavenie, o čom svedčí ročne narastajúci záujem o zverejnenie zaslaných príspevkov. Jeho vydávaním $\mathrm{v}$ anglickom jazyku v printovej a elektronickej forme redakcia promptne reagovala na požiadavky moderných foriem šírenia odborných informácií, čo možno obzvlášt' ocenit’ v súčasnej „covidovej dobe“. Spolupútnikom profesora Hulína je PhDr. Helena Bernadičová, ktorá nie ovel'a kratšie „drží časopis“ najmä z hl'adiska „,vysokej kultúry 
textov“. Je to priam obdivuhodná súbežnost' dvoch odborností pri tvorbe časopisu a dosahovaní jeho vrcholov.

Bratislavské lekárske listy sú hodnotným dielom, národným kultúrnym dedičstvom, ktoré je výsledkom práce výnimočných, múdrych, vzdelaných l'udí nezištne sa podiel'ajúcich na jeho tvorbe, na ktorých môžeme byt' právom hrdí. Vážime si a oceňujeme, že napriek náročným spoločenským udalostiam, vrátane zložitého obdobia transformácie nášho zdravotníctva s jej závažnými ekonomickými dopadmi na vzdelávanie a vydávanie odbornej literatúry, dokázali zachovat' a zvyšovat' odbornú úroveň a kvalitu časopisu. Osobnosti, akými sú prof. Hulín a členovia redakčnej rady Bratislavských lekárskych listov, sú zárukou, že časopis bude zachovaný aj nad'alej vo vysokej kvalite a bude jedným z nástrojov odborného vzdelávania budúcich generácií lekárov a zdravotníckych pracovníkov v d’alšom storočí. Verím tomu a želám to členom redakčnej rady, prispievatel'om a širokej odbornej medicínskej komunite.

Dr.h.c. prof. MUDr. Ján Breza, DrSc., MPH, MHA prezident Slovenskej lekárskej spoločnosti 